\title{
PENGARUH PEMBELAJARAN PROBLEM BASED LEARNING TERHADAP KEMAMPUAN METAKOGNITIF DAN PEMECAHAN MASALAH MATEMATIKA DI KELAS XI SMA NEGERI 1 JOMBANG
}

\author{
Nurul Istiqomah \\ Program Studi Pendidikan Matematika, FMIPA, Universitas Negeri Surabaya \\ nurulistiqomah3@mhs.unesa.ac.id \\ Tatag Yuli Eko Siswono \\ Program Studi Pendidikan Matematika, FMIPA, Universitas Negeri Surabaya \\ tatagsiswono@unesa.ac.id
}

\begin{abstract}
Abstrak
Peneliti mengambil riset ini untuk mencari tahu tentang pengaruh penerapan pembelajaran model problem based learning pada kemampuan metakognitif dan pemecahan masalah dalam belajar, khususnya mata pelajaran matematika. Penelitian ini menggunakan pendekatan kuantitatif dan metode eksperimen bentuk true experiment. Sampel penelitian ini menggunakan teknik sampling purposive. Untuk menguji hipotesis yang dipaparkan pada awal penelitian, teknik pengolahan data untuk riset ini menerapkan uji-t. Dari runtutan aktivitas penelitian dan pengolahan data tersebut, diketahui bahwa hasil akhir nilai koefisien $\boldsymbol{t}_{\text {hitung }}>\boldsymbol{t}_{\text {tabel }}$. Sehingga berpedoman dari hasil data yang diperoleh, dapat disimpulkan bahwa model problem based learning berpengaruh pada kemampuan metakognitif. Hasil analisis data lainnya dari pemecahan masalah dalam menyelesaikan persoalan matematika, diketahui hasil akhir nilai koefisien $\boldsymbol{t}_{\text {hiutng }}>\boldsymbol{t}_{\text {tabel }}$. Dari hal tersebut dapat disimpulkan lagi bahwa model problem based learning juga berpengaruh terhadap pemecahan masalah dalam menyelesaikan persoalan matematika.

Kata Kunci: pembelajaran problem based learning, kemampuan metakognitif, pemecahan masalah matemaika.
\end{abstract}

\section{Abstract}

Researchers took this research to find out about the effects of the application of problem-based learning models on metacognitive abilities and problem-solving in education, especially mathematics. This research uses a quantitative approach, and the experimental method forms an actual experiment. This research uses a quantitative approach, and the experimental method forms an actual experiment. This research sample uses purposive sampling technique. From the sequence of research and data processing activities, it is known that the final result is the coefficient value $\boldsymbol{t}_{\text {hiutng }}>\boldsymbol{t}_{\text {tabel }}$. So based on the results of the data obtained, it can conclude that the problem-based learning model influences metacognitive abilities. While the results of other data analysis of problem-solving in solving mathematical problems, the final results obtained coefficient values $\boldsymbol{t}_{\text {hiutng }}>\boldsymbol{t}_{\text {tabel }}$. From this, it can conclude again that the model of problem-based learning also affects the problem-solving in solving mathematical problems.

Keywords: problem based learning, metacognitive ability, mathematical problem solving.

\section{PENDAHULUAN}

Matematika didefinisikan dengan suatu ilmu yang pasti. Tidak bisa dipungkiri bahwa matematika merupakan salah satu ilmu pengetahuan yang sangat penting dalam kehidupan sehari-hari hingga tidak terkecuali dalam kegiatan pembelajaran di sekolah. Dalam hal ini dapat dibuktikan dengan banyaknya beberapa cabang ilmu pengetahuan yang didasarkan pada konsep pengembangan ilmu matematika. Namun disisi lain bicara soal matematika sesungguhnya merupakan momok yang sangat menakutkan dan menjenuhkan untuk dipelajari bagi para peserta didik baik mulai dari jenjang SD, SMP, hingga SMA. Matematika memang memiliki tingkat kesulitan yang sangat tinggi apabila dibandingkan ilmu pengetahuan lainnya. Dari persoalan dilapangan, selain faktor pendidikan dan peserta didik itu sendiri beberapa hal yang mendasari diantaranya juga disebabkan karena penggunaan metode pembelajaran matematika yang masih cenderung kurang menarik dan terlalu monoton sehingga berimbas pada kurang efektif dan efisiennya kegiatan belajar mengajar di dalam kelas. Kecenderungan pendidik 
yang masih banyak menggunakan metode konvensional dalam menyampaikan materi juga berpengaruh pada proses belajar peserta didik. Kondisi seperti inilah yang membuat para peserta didik kurang maksimal untuk berkreasi dalam belajar sehingga sulit memahami apalagi untuk menyelesaikan persoalan matematika.

Istilah pembelajaran merupakan rangkaian aktivitas belajar yang dibentuk pendidik untuk menumbuhkan keaktifan dan kreativitas peserta didik dalam berpikir. Dalam kutipan Suyono, dkk. (2012:15) mendefinisikan pembelajaran sebagai "ilmu yang didapat dari sebuah pengalaman. (UNEP, 2007:4)".

Dari persoalan tersebut kuncinya adalah pemilihan metode yang efektif dan efisien dalam kegiatan pembelajaran merupakan tolak ukur untuk mendukung kemampunan metakognitif dan kreatifitas peserta didik dalam memecahkan persolaan dalam belajar. Pembelajaran yang efektif tidak terlepas dari peran serta pendidik dalam mendesain atau menerapkan model-model pembelajaran kreatif yang berpusat pada peserta didiknya (learned centered), apalagi yang berkaitan erat dengan proses pemecahan masalah (problem solving) dalam belajar. Dengan melibatkan peran aktif peserta didik dalam setiap proses kegiatan pembelajaran dapat berpengaruh juga dengan meningkatnya prestasi belajar peserta didik khususnya dalam bidang matematika. Sehubungan dengan pemilihan dan penerapan model pembelajaran yang tepat salah satunya yaitu dengan mengimplementasikan pembelajaran berbasis masalah di dalam kelas.

Barrow (1980) seperti yang dikutip oleh Miftahul (2014:271) mengistilahkan metode problem based learning merupakan "pengalaman dalam belajar yang didapat dari aktivitas memahami dan memecahkan sebuah masalah yang seringkali dijumpai dari setiap proses pembelajaran". Pernyataan selaras juga dijelaskan oleh Ali Muhson (2009:173) mengartikan metode problem based learning sebagai dasar untuk mengolah dan mengadaptasi menjadi sebuah ilmu atau pengalaman baru. Metode tersebut yang mana sangat mendukung peserta didik untuk dapat berpikir aktif kreatif dalam menganalisis dan menyelesaikan berbagai persoalan matematika dengan kemampuan yang dimilikinya. Dalam hal ini dapat diperjelas bahwa fokusnya terletak pada pembelajaran peserta didik, bukan pada pengajaran dari pendidik.

Kemampuan pemecahan masalah dalam pembelajaran matematika merupakan hal utama yang mendorong peserta didik untuk dapat menyelesaikan setiap permasalahan secara aktif dan kreatif. Pada dasarnya pembelajaran berbasis masalah dalam matematika tidak hanya untuk melatih proses belajar peserta didik, tapi lebih bertujuan untuk melatih kemampuan berpikir peserta didik tentang apa yang ada dipikirannya. Dalam hal ini erat kaitannya dengan kreativitas peserta didik untuk mengembangkan berbagai cara memecahkan permasalahan yang ada.

Pembelajaran matematika berbasis masalah yang dikemas dengan konsep lebih menarik dapat memberikan kesempatan peserta didik untuk dapat bekompetisi dalam meningkatkan kemampuan metakognitifnya dalam menyelesaikan permasalahan baik secara kelompok ataupun individu. Disamping itu juga hal tersebut dapat menghilangkan kesan negatif selama ini yang berhubungan dengan mata pelajaran matematika. Salah satu solusinya adalah dengan penyajian pembelajaran dalam bentuk soal cerita sebagai tolak ukur mengetahui peningkatan kemampuan metakognitif pada setiap peserta didik. Dari beberapa faktor pendukung perilaku metakognitif dalam menyelesaikan persoalan matematika diantara dapat dilihat dari sisi kemampuan perencanaan awal, kemampuan memprediksi, kemampuan monitoring hingga pengujian, dan terakhir kemampuan untuk mengevaluasi keseluruhan dari awal. Hal itu selaras dengan tujuan pada kurikulum 2013 yang berorientasi untuk mengembangkan ketrampilan peserta didik dalam memecahkan sebuah masalah dalam belajar. Murtadho (2013) menjelaskan kemampuan metakognitif sebagai strategi berpikir yang berurutan untuk mengontrol perilaku dan memastikan tujuan kognitif sudah tercapai. Sedangkan pemecahan masalah dalam pembelajaran menurut Dwijanto (2007) merupakan pendekatan dalam pembelajar sekaligus tujuan yang harus dicapai di dalamnya.

Dari tinjauan lapangan diperoleh sebagian besar peserta didik mengalami kesulitan atau kendala ketika dihadapkan dengan soal-soal bentuk cerita maupun uraian lainnya. Disamping itu juga persoalan lain ialah kendala peserta didik dalam membuat ataupun mengajukan pertanyaan tiap contoh persoalan yang disajikan. Hal itu semua dikarenakan kurang mandirinya peserta didik yang selalu menunggu penjelasan akhir dari pendidik dalam memberikan rumus daripada mencarinya sendiri, selain itu dimana peserta didik juga lebih condong hanya memikirkan hasil akhir sebuah permasalahan yang telah disajikan.

Kemampuan metakognitif sendiri mempunyai peranan yang sangat penting dalam pembelajaran matematika khususnya pemecahan masalah, dimana peserta didik akan sadar tentang proses berpikir dan mengevaluasi kemampuan diri sendiri terhadap hasil dari proses belajarnya. Hal tersebut yang meminimalisir kesalahan dalam penyelesaian masalah.

Selaras dengan penjabaran dari Flaver (Usman, 2014) yang menyebutkan bahwa kemampuan metakognitif sebagai suatu bentuk kemampuan untuk menilai pada diri sendiri sehingga apa yang dilakukan dapat terkontrol 
optimal. Pengetahuan ini sangat penting karena peserta didik dapat belajar dan menyelesaikan persoalan secara sistematis dan berhati-hati dengan adanya kontrol dari dalam diri tersebut.

Pembelajaran yang diharapkan dalam hal ini dapat meningkatkan kemampuan metakognitif peserta didik yaitu dengan penggunaan metode problem based learning. Metode ini adalah sebuah model pembelajaran yang yang mengutamakan permasalahan di dalam penyajiannya. Dengan keberagaman cara penyelesaian tersebut sehingga memberikan kebebasan peserta didik dalam memahami hingga menyelesaikan tiap persoalan matematika yang ada. Hal ini juga yang tentunya akan mengembangkan berbagai strategi penyelesaian persoalan matematika yang dihadapi oleh peserta didik. Selain itu pembelajaran ini membantu membantu peserta didik dalam melakukan perencanaan, penyelesaian, monitoring hingga evaluasi terhadap hasil belajar yang sudah dilakukan. Sehingga pembelajan dengan metode problem based learning ini diharapkan dapat meningkatkan kemampuan metakognitif peserta didik.

Berdasarkan uraian diatas, adapun tujuan utama penelitian ini untuk mencari tahu seberapa besar pengaruh metode problem based learning yang diterapkan dalam pembelajaran terhadapat kemampuan metakognitif dan pemecahan persoalan matematika pada peserta didik kelas XI SMA Negeri 1 Jombang.

\section{METODE}

Jenis penelitian ini merupakan penelitian dengan pendekatan kuantitatif dan menggunakan metode ekperimen dengan bentuk eksperimen sejati (true experiment). Dikatakan penelitian (true experiment) karena prinsip ekuivalensi antara kelompok kontrol dan ekspermen dipenuhi melalui pemilihan acak serta dilakukan pengendalian (Siswono, 2018).

Tabel 1. Rancangan Penelitian

\begin{tabular}{|c|c|c|}
\hline Kelompok & Perlakuan & Tes \\
\hline Eksperimen & $x$ & $M_{1}$ \\
\hline Kontrol & - & $M_{2}$ \\
\hline
\end{tabular}

(Siswono,2018)

Sampel penelitian ini mengambil seluruh peserta didik dari dua kelas XI SMA Negeri 1 Jombang. Berdasarkan observasi di sekolah, diperoleh hasil peserta didik bahwa kelas-kelas di SMA Negeri 1 Jombang homogen karena penempatan peserta didik tidak bersarkan kemampuan yang dimiliki.

Teknik sampling data dalam penelitian ini menggunakan metode tes sesudah kegiatan pembelajaran. Selanjutnya observasi dilakukan oleh pengamat saat berlangsungnya rangkaian aktivitas pembelajaran. Diantaranya dalam hal ini menggunakan teknik analisis data :

- Uji Normalitas

Hal ini dalam penelitian digunakan untuk membuktikan apakah semua sampel penelitian berdistribusi normal atau tidak. Pada uji ini juga digunakan yang namanya rumus Kolmogorov-Smirnov dalam proses hitungnya menggunakan software SPSS.

- Uji Homogenitas

Teknik analisis ini dalam penelitian digunakan setelah diketahui akan tingkat kenormalan datanya. Tujuan dari uji homogenitas adalah untuk membuktikan tingkat kesamaan varians antara kedua sampel, yang mana sampel disini adalah sebagai control class dan experiment class.

- Uji Hipotesis

Hal ini dalam penelitian digunakan untuk membandingkan antara 2 buah sampel penelitian dengan menggunakan teknik analisis Paired Sampel $t$ tes. Teknik tersebut digunakan untuk mengetahhui perbedaan rata-rata dalam sebuah sampel yang diberikan perlakuan berbeda. Untuk melihat perbedaan rata-rata dan tolak ukur tinggi rendahnya dari sampel penelitian yang digunakan sebelum dan setelah diberi perlakuan. Adapun hipotesis yang dikaji dalam penelitian ini adalah "adakah pengaruh pembelajaran problem based learning terhadap kemampuan metakognitif dan pemecahan masalah matematika di kelas XI SMA Negeri 1 Jombang”. Dalam uji paired sampel t test ini menggunakan rumus :

$$
t=\frac{\bar{x}_{1}-\bar{x}_{2}}{\sqrt{\frac{s_{1}^{2}}{n_{1}}+\frac{s_{2}^{2}}{n_{2}}-2 r\left(\frac{s_{1}}{\sqrt{n_{1}}}\right)\left(\frac{s_{2}}{\sqrt{n_{2}}}\right)}}
$$

\section{HASIL DAN PEMBAHASAN}

Penelitian eksperimen ini diujikan pada kelas XI SMA Negeri 1 Jombang sebagai sampelnya. Pada tahap awal penelitian ini ingin mencari tahu terlebih dahulu ada tidaknya pengaruh dari penerapan pembelajaran berbasis masalah terhadap hasil belajar peserta didik, dengan cara diterapkan beda perlakuan pada tia-tiap kelas sampel. Dalam hal ini peneliti menjadikan kelas XI MIA 3 sebagai sampel experiment class yang diberikan penerapan pembelajaran menggunakan metode problem based learning, lainnya sebagai kelas kontrol dari XI MIA 4 yang diberikan penerapan pembelajaran metode konvensional seperti pada umumnya.

Sebelum penelitian dilakukan, terlebih dahulu diberikan tes awal pada tiap-tiap sampel. Aktivitas ini 
bertujuan menyakinkan kesamaan kemampuan awal diantara dua kelas sampel tersebut.

Setelah diketahui bahwa peserta didik pada kelas eksperimen dan kelas kontrol memiliki kesamaan kemampuan, barulah pada masing-masing kelas tersebut diterapkan perlakuan pembelajaran dengan metode yang berbeda. Pada tahap selanjutnya atau tahap akhir, kedua kelas sampel tersebut diberikan post test. Hal ini bertujuan agar diketahuinya kemampuan pemecahan masalah pada peserta didik dalam proses penyelesaian setiap persoalan pelajaran matematika.

a. Sampling Data Tahap Kemampuan Awal Kelas Sampel

Data kemampuan awal peserta didik adalah skor hasil tes prasyarat sebelum penelitian dimulai, adapun materi yang diujikan adalah program linear. Berdasarkan Tabel (2) dapat diamati hasil tes awal pada peserta didik

Tabel 2. Hasil Pre-Test Kelas Sampel

\begin{tabular}{|c|c|c|c|c|c|}
\hline Sampel & $\mathrm{N}$ & $\begin{array}{c}\text { Nilai } \\
\text { Terendah }\end{array}$ & $\begin{array}{c}\text { Nilai } \\
\text { Tertinggi }\end{array}$ & Rerata & $\begin{array}{c}\text { Standart } \\
\text { Deviasi }\end{array}$ \\
\hline $\begin{array}{c}\text { Kelas } \\
\text { Eksperimen }\end{array}$ & 34 & 43 & 73 & 55,83 & 6,66 \\
\hline $\begin{array}{c}\text { Kelas } \\
\text { Kontrol }\end{array}$ & 35 & 47 & 71 & 55,84 & 5,24 \\
\hline
\end{tabular}

Pada Tabel. 2 dapat diamati bahwa kemampuan awal peserta didik kelas eksperimen sebelum diberikan perlakuan, dimana skor terendahnya 43 dan skor tertingginya 73 , dengan skor rataan 55, dengan standart deviasi 6.66.

Karena rerata skor kemampuan awal matematika yang idcapai peserta didik pada kedua sampel diperoleh nilai yang tidak terlalu jauh yaitu 55,84 untuk kelas kontrol maka dapat disimpulkan bahwa skor kemampuan awal matematika peserta didik pada kedua kelas sampel adalah seimbang.

b. Sampling Data Tahap Akhir Kemampuan Metakognitif

Data akhir dari masing-masing sampel penelitian dapat dilihat pada statistik deskriptif data kemampuan metakognitif berikut.

Tabel 3. Hasil Post Test Kemampuan Metakognitif

\begin{tabular}{|l|c|c|c|c|c|}
\hline Sampel & N & $\begin{array}{c}\text { Skor } \\
\text { Terendah }\end{array}$ & $\begin{array}{c}\text { Skor } \\
\text { Tertinggi }\end{array}$ & Rerata & $\begin{array}{c}\text { Std. } \\
\text { Deviasi }\end{array}$ \\
\hline $\begin{array}{l}\text { Kelas } \\
\text { Eksperimen }\end{array}$ & 34 & 43 & 86 & 70,2 & 12,38 \\
\hline
\end{tabular}

\begin{tabular}{|l|c|c|c|c|c|}
\hline $\begin{array}{l}\text { Kelas } \\
\text { Kontrol }\end{array}$ & 35 & 47 & 93 & 59,6 & 22,42 \\
\hline
\end{tabular}

Sumber: Data diolah sendiri

Rerata skor kemampuan metakognitif matematika yang dicapai pada peserta didik kedua sampel diperoleh nilai terlalu berbeda jauh yaitu 70,2 untuk kelas eksperimen dan 59,6 untuk kelas kontrol maka dapat disimpulkan bahwa skor kemampuan metakognitif matematika peserta didik kelas ekperimen dan kelas kontrol adalah tidak seimbang, dengan kata lain rerata kelas ekperimen dan kelas kontrol ada perbedaan. Tidak berimbangnya kemampuan metakognitif matematika pada kedua sampel dapat dicermati dari diagram batang. Maka berdasarkan itu semua dapat disimpulkan kalau dari kedua kelas sampel terdapat perbedaan.

Dari hasil penelitian diperoleh bahwa hasil belajar pada kelas experiment dengan penerapan model problem based learning terdapat peningkatan lebih tinggi daripada kelas kontrol dengan metode pembelajaran konvensionalnya.

Gambar 1. Diagram Hasil Uji Kemampuan

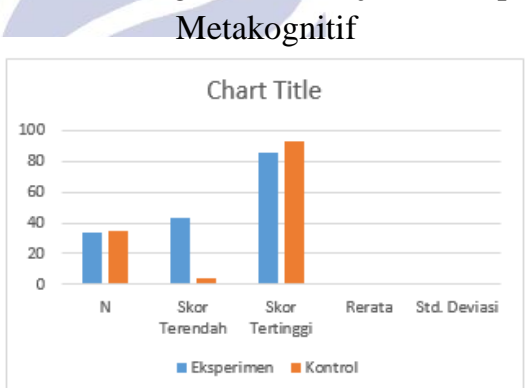

Sumber: Data diolah sendiri

c. Data Hasil Pemecahan Masalah Matematika

Data pemecahan masalah matematika peserta didik dari masing-masing sampel penelitian dapat dilihat pada statistik deskriptif tabel berikut:

Tabel 4. Hasil Test Penyelesaian Masalah Matematika

\begin{tabular}{|c|c|c|c|c|}
\hline \multirow{2}{*}{ No } & \multicolumn{2}{|c|}{ Kelas Eksperimen } & \multicolumn{2}{c|}{ Kelas Kontrol } \\
\cline { 2 - 5 } & Pre test & Post test & Pre test & Post test \\
\hline \multirow{2}{*}{1} & Nilai & Nilai & Nilai & Nilai \\
& Maximum & Maximum & Maximum $=$ & Maximum $=$ \\
& $=64$ & $=96$ & 64 & 92 \\
\hline \multirow{2}{*}{2} & Nilai Min. & Nilai Min. & Nilai Min. & Nilai Min. \\
& $=2$ & $=62$ & $=2$ & $=62$ \\
\hline \multirow{2}{*}{3} & Mean $=$ & Mean $=$ & Mean $=$ & Mean $=$ \\
& 31,57 & 83,43 & 34,48 & 79,67 \\
\hline \multirow{3}{*}{4} & Standart & Standart & Standart & Standart \\
& Deviasi $=$ & Deviasi $=$ & Deviasi $=$ & Deviasi $=$ \\
& 16,29 & 10,05 & 16,31 & 10,45 \\
\hline
\end{tabular}




\begin{tabular}{|c|c|c|c|c|}
\hline 5 & $\begin{array}{c}\text { Varian = } \\
251,12\end{array}$ & $\begin{array}{c}\text { Varian }= \\
100,98\end{array}$ & $\begin{array}{c}\text { Varian }= \\
265,92\end{array}$ & $\begin{array}{c}\text { Varian }= \\
109,16\end{array}$ \\
\hline
\end{tabular}

Sumber: Data diolah sendiri

Berdasarkan analisis data diatas dapat diuraikan bahwa analisis hasil pre-test kemampuan pemecahan masalah matematika dari 34 peserta didik pada kelas eksperimen benilai $=31,57$, standar deviasi $=16,29$ dan variansi $=16,29$. Analisis hasil post test kemampuan pemecahan masalah matematika pada kelas experiment benilai $=83,43$, standart deviasi bernilai $=10,05$ dan variansi bernilai $=100,98$.

Disisi lain sampel kelas kontrol sebagaimana rincian analisis pada tabel diatas dari 35 peserta didik menunjukkan hasil yang berbeda berdasarkan perhiyungan pre-test kemampuan pemecahan masalah.

\section{- Uji Normalitas}

Berikut tabel data hasil dari perhitungan uji normalitas dengan menggunakan SPSS:

Tabel 5. Uji Kemampuan Metakognitif

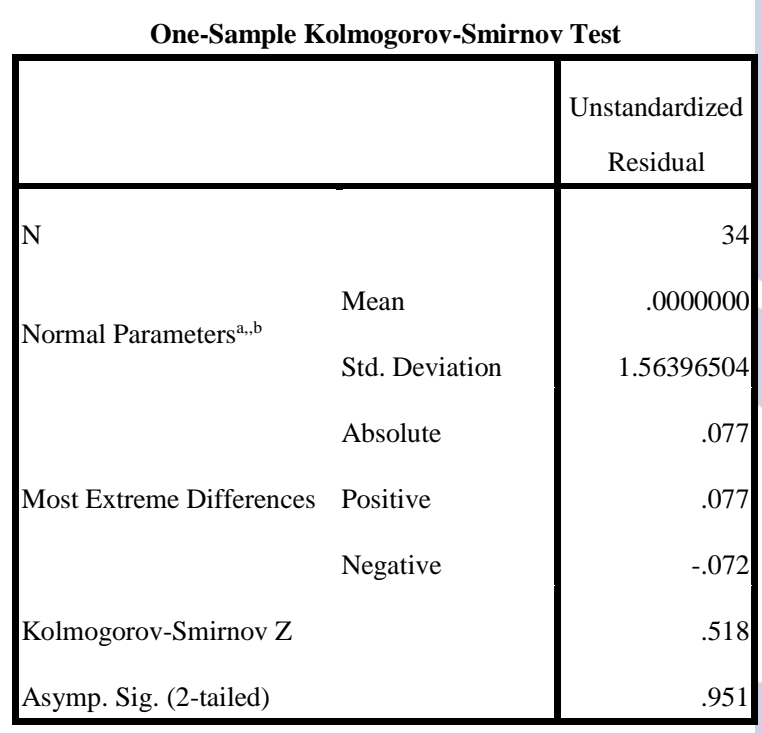

a. Test distribution is Normal.

b. Calculated from data.

(Sumber: Data diolah sendiri)

Hasil kemampuan metakognitif yang diperoleh membuktikkan nilai Asymp.Sig (2-tailed) = 0,951 yang mana lebih besar dari 0,05. Sesuai dengan dasar pengambilan keputusan dalam uji normalitas komogorov-smirnov di atas, dapat disimpulkan bahwa data berdistribusi normal.

Tabel 6. Uji Normalitas Pemecahan Masalah One-Sampel Kolmogorov-Smirnov Test

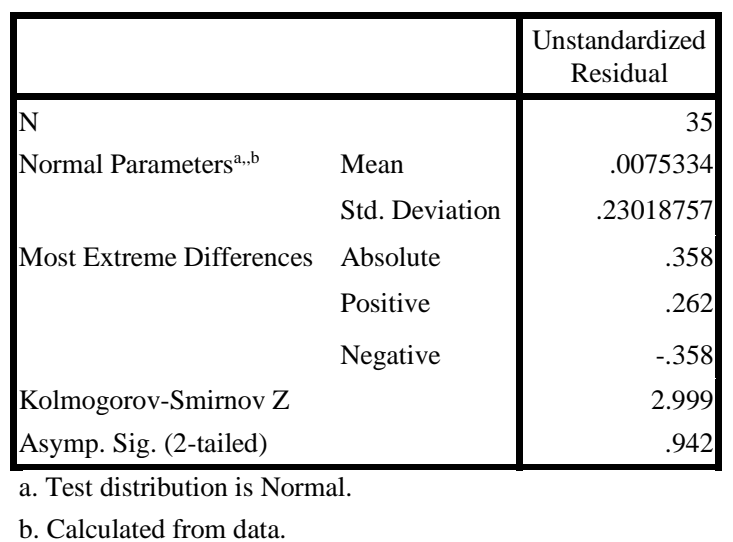

(Sumber: Data diolah sendiri)

Hasil pemecahan masalah matematika yang diperoleh membuktikkan kalau nilai Asymp.Sig (2tailed) lebih besar dari 0,05 maka ditarik kesimpulan data berdistribusi normal.

\section{Uji Homogenitas}

Metode ini dilakukan menggunakan fungsi univariate pada SPSS dengan kriteria jika nilai signifikan kurang dari 0,05.

Tabel 7. Uji Kemampuan Metakognitif Test of Homogeneity of Variances

\begin{tabular}{r|r|r|r|}
\hline Levene Statistic & \multicolumn{1}{|c|}{ df1 } & df2 & \multicolumn{1}{c|}{ Sig. } \\
\hline 10.641 & 1 & 67 & .072 \\
\hline \multicolumn{4}{|c}{ Sumber: Data diolah sendiri } \\
Dari tabel diatas, kemampuan metakognitif dengan
\end{tabular}
menggunakan uji homogenitas diketahui bahwa variabel hasil nilai signifikansi (Sig.) kedua kelas sampel sebesar 0,072. Berdasarkan pengambilan keputusan dalam uji homogenitas, distribusi data hasil kemampuan metakognitif pada peserta didik dari kedua kelas sampel adalah homogen.

Tabel 8. Uji Homogenitas Pemecahan Masalah Test of Homogeneity of Variances

\begin{tabular}{|c|c|c|c|}
\hline Levene Statistic & df1 & df 2 & Sig. \\
\hline .092 & 1 & 67 & .762 \\
\hline
\end{tabular}

Hasil pemecahan masalah matematika dengan menggunakan uji homogenitas diketahui bahwa variabel hasil nilai signifikansi (Sig.) kedua kelas sampel sebesar 0,762. Dari sini dapat ditarik kesimpulan berdasarkan pengambilan keputusan dalam uji homogenitas, distribusi data hasil pemecahan 
masalah matematika pada peserta didik dari kedua kelas sampel adalah homogen.

\section{- Uji Hipotesis}

Mengetahui sebaran data kemampuan metakognitif dan pemecahan masalah matematika berdistribusi homogen dan normal. Tahap berikutnya adalah melakukan uji hipotesis dengan menggunakan analisis varians satu jalur. Adapun hasil pengujian variabel kemampuan metakognitif dan variabel pemecahan masalah dirangkum pada tabel berikut :

Tabel 9. Hasil Uji Hipotesis Kemampuan Metakognitif

\begin{tabular}{|c|c|c|c|}
\hline \multirow{2}{*}{ No } & \multirow{2}{*}{ Statistik } & \multicolumn{2}{|c|}{ Sampel } \\
\cline { 3 - 4 } & & $\begin{array}{c}\text { Experiment } \\
\text { Class }\end{array}$ & Control Class \\
\hline 1 & Rataan & 83,43 & 79,67 \\
\hline 2 & $\begin{array}{c}\text { Standart } \\
\text { Deviasi }\end{array}$ & 10,05 & 10,45 \\
\hline 3 & Varians & 100,98 & 109,16 \\
\hline 4 & Jumlah & 34 & 35 \\
\hline & $\mathrm{t}_{\text {hitung }}$ & 8,6519 & 6,1995 \\
\hline & $\mathrm{t}_{\text {tabel }}$ & 2,0211 & 2,0211 \\
\hline & Kesimpulan & Ha diterima & Ha diterima \\
\hline
\end{tabular}

Sumber: Data diolah sendiri

Dapat disimpulkan dari hasil hipotesis terdapat adanya perbedaan hasil belajar setelah penerapan metode problem based learning, mengamati hasil $t_{\text {hitung }}$ $(8,6519)$ dan $t_{\text {tabel }}$ pada taraf $(\alpha=0,05)=2,0211$ yang membuktikan bahwa nilai koefisien $t_{\text {hitung }}>t_{\text {tabel }}$.

Tabel 10. Hasil Uji Hipotesis Pemecahan Masalah

\begin{tabular}{|c|c|c|c|}
\hline \multirow{2}{*}{ No } & \multirow{2}{*}{ Statistik } & $\begin{array}{c}\text { Experiment } \\
\text { Class }\end{array}$ & Control Class \\
\cline { 3 - 4 } & Rataan & 71,33 & 67,87 \\
\hline 1 & Standar Deviasi & 9,23 & 8,12 \\
\hline 3 & Varians & 101,19 & 100,27 \\
\hline 4 & Jumlah & 34 & 35 \\
\hline & $\mathrm{t}_{\text {hitung }}$ & 7,4529 & 6,0415 \\
\hline & $\mathrm{t}_{\text {tabel }}$ & 2,0211 & 2,0211 \\
\hline & Kesimpulan & Ha diterima & Ha diterima \\
\hline
\end{tabular}

Berdasarkan hasil analisis tersebut diperoleh $t_{\text {hitung }}=7,4529$ dan nilai $t_{\text {tabel }}$ pada taraf $(\alpha=0,05)=$ 2,0211. Hal ini membuktikan bahwa nilai koefisien $t_{\text {hitung }}>t_{\text {tabel }}$. Berdasarkan hasil analisis tersebut dapat disimpulkan bahwa hipotesis dapat terbuktikan dengan adanya pengaruh hasil belajar yang menerapkan metode pemecahan persoalan matematika.

Dari analisis hasil rangkaian aktivitas penelitian, rataan nilai kemampuan metakognitif dan pemecahan masalah matematika dari kedua kelas sampel memiliki kondisi yang sama. Dimana dari hasil data penelitian menunjukkan nilai kelas eksperimen 23,11 dan kelas kontrol 12,23. Kesimpulannya adalah tidak ada perbedaan yang jauh rataan hasil kemampuan metakognitif dengan rataan hasil pemecahan masalah dari kedua kelas sampel.

Hasil belajar peserta didik pada model problem based learning lebih tinggi dibandingkan dengan nilai hasil belajar pada penerapan pembelajaran konvensional. Dalam pembelajaran model problem based learning peserta didik diharapkan pada permasalahan yang ada di dunia nyata dan pertanyaan yang berhubungan dengan penyelesaian soal cerita pada mata pelajaran matematika. Permasalah belajar dapat bersumber dari dalam atau dari kehidupan nyata, sehingga termotivasi untuk dapat menyelesaikan berbagai macam persoalan matematika yang disajikan dan mengasah kemampuan metakognitif masingmasing individu sehingga berdampak pada hasil belajar peserta didik tersebut.

Beberapa hal yang menyebabkan kemampuan pemecahan masalah kelas experimen lebih tinggi dibandingkan kelas konvensional dimana pada pembelajaran model problem based learning pembelajaran diawali dengan memberikan sebuah permasalahan persoalan matematika. Kemudian peserta didik diminta untuk dapat menyelesaikannya dengan cara berdiskusi, melakukan pengkajian, hingga mengembangkan cara penyelesaian dari permasalahan sesuai petunjuk yang sudah pendidik paparkan. Dari hal tersebut, peserta didik lebih sering bertanya apa yang belum dipahami sehingga pendidik lebih mudah memantau perkembangan proses belajar yang sedang berlangsung. Dari proses terebutlah yang membuat peserta didik lebih mandiri dan kreatif dalam menyusun perencanaan belajar. Dengan tahapan belajar yang seperti ini pula membuat peserta didik lebih aktif dan terlalih untuk mengungkapkan ide-ide penyelesaian persoalan matematika sehingga kemampuan pemecahan masalah pada pserta didik dapat beekembang lebih baik.

Pada pertemuan awal, peserta didik masih banyak mengalami kesulitan belajar sehingga pembelajaran masih belum bisa berjalan optimal. Dari hal tersebut, pendidik mengevaluasi apa saja yang dirasa kurang dan perlu dikembangkan dalam proses pembelajaran yang ada. Pada pertemuan selanjutnya peserta didik sudah mulai memahami cara pembelajaran yang disajikan. Sehingga proses belajar mengajar di dalam kelas sudah mulai bisa berjalan efektif dimana beberapa peserta didik sudah dapat menyelesaikan dan memahami sendiri dari persoalan belajar matematika. 
Berbeda dengan kelas konvensional, dimana peserta didik hanya memperoleh informasi atau pelajaran dari apa yang diterangkan oleh pendidik saja. Pada saat proses pembelajaran setelah memberikan materi, peneliti mencoba untuk memberikan kesempatan pada peserta didik untuk bertanya apabila ada hal yang dirasa kurang jelas dalam penyampaian materinya, namun hanya beberapa peserta didik saja yang aktif bertanya. Dan saat peneliti memberikan kesempatan untuk menyelesaikan permasalahan tentang materi yang dipelajari, juga didapati beberapa peserta didik saja yang aktif.

Berdasarkan hal tersebut, peserta didik kurang aktif dalam proses pembelajaran. Selain itu juga pada proses penyelesaian soal juga terpaku satu cara yang diajarkan oleh pendidik saja, sehingga peserta didik tidak mampu untuk mengembangkan ide-ide mereka secara optimal dan menyebabkan suasana pembelajaran menjadi pasif.

Dilihat dari analisis hasil hipotesis juga dapat ditarik kesimpulan bahwa terdapat pengaruh prestasi belajar dari penerapan pembelajaran metode problem based learning. Hakikatnya konsep dari pembelajaran ini tidak di desain bagi pendidik untuk harus memaparkan banyak hal dan menjelaskan sedetaildetailnya keseluruhan bab pelajaran yang sedang disampaikan kepada peserta didik. Tetapi hakikat konsep problem based learning dirancang dan dikembangkan untuk melatih dan menumbuhkan kreativitas berpikir, kreativitas dalam memecahkan masalah dan kreativitas keterampilan intelektual. Sebab belajar adalah sebuah pengalaman langsung dari keterlibatan seseorang dalam pembelajaran nyata atau simulasi, baik secara kelompok bahkan individu (Yatim Riyanto, 2015:288).

Berdasarkan hal tersebut dimana semula metode konvensional yang terlalu monoton sering digunakan oleh pendidik, diharapkan dengan penerapan metode pembelajaran ini (problem based learning) dapat menumbuhkan dan melatih rasa keingin tahuan peserta didik dalam proses pembelajaran. Disisi lain, tidak terlepas juga dengan penerapan metode ini dapat merubah mainset negatif peserta didik selama ini tentang matematika yang menjadi momok sebuah mata pelajaran yang membosankan dan menakutkan. Sehingga dari sini peserta didik lebih dapat termotivasi, menyukai, dan utamanya lebih mudah untuk memahami mata pelajaran matematika yang sedang dipelajari di ruang kelas.

\section{PENUTUP \\ Simpulan}

Berdasarkan pembahasan dan analisis keseluruhan aktivitas penelitian dapat disimpulkan: (1) Diketahui dari hasil hipotesis yang membuktikan bahwa terdapat perbandingan kemampuan peserta didik ketika sebelum dan sesudah diterapkan metode tersebut dalam kegiatan belajar mengajar. Dimana dari analisis tersebut menunjukkan bahwa nilai $t_{\text {hitung }}>t_{\text {tabel }}$. Dapat disimpulkan bahwa terdapat pengaruh pada kemampuan metakognitif dan pemecahan persoalan belajar matematika dari penerapan pembelajaran model problem based learning di kelas XI SMA Negeri 1 Jombang. (2) Dari sampling hasil dan proses analisis data penelitian menunjukkan rataan nilai kelas eksperimen 23,11 sedangkan rataan nilai kelas kontrol 12,23. Dapat disimpulkan bahwa penerapan model problem based learning menunjukkan pengaruh terhadap proses dan hasil belajar menjadi lebih baik daripada pembelajaran konvensional dalam meningkatkan kemampuan metakognitif dan pemecahan persoalan matematika.

\section{Saran}

Dari keseluruhan aktivitas penelitian, beberapa masukan darii peneliti yang perlu disampaikan adalah: (1) Agar kiranya model pembelajaran ini, khususnya problem based learning dapat diterapkan sebagai alternative upaya untuk meningkatkan kemampuan metakognitif dan pemecahan masalah dalam pembelajaran matematika disekolah. (2) Setidaknya pendidikan lebih sering melibatkan peserta didik dalam aktivitas belajar dalam kelas. Adanya penerapan problem based learning diharapkan mampu mendorong peserta didik untuk lebih aktif terlibat langsung dalam kegiatan pemecahan persoalan matematika yang ada. (3) Dari penelitian ini diinginkan dapat menjadi pedoman untuk mengembangkan penelitian lebih lanjut dan menjadi dasar pertimbangan yang lebih efektif dan efisien.

\section{DAFTAR PUSTAKA}

Abdullah, In Hi. 2013. Berpikir Kritis Matematik. Jurnal Matematika dan Pendidikan Matematika. Universitas Khairun. Vol. 2 No. 1: 66-75.

Adams, Wendy Kristine. 2007. Development of a Proble Solving Evaluation Instrumen; untangling of specific problem solving skills. Facully of the Graduate Schoolof the University of Colorado.

Arend, R.I. 2007. Belajar untuk Mengajar. Jakarta: Salemba Humanika.

Arikunto, S. 2010. Prosedur Penelitian Suatu Pendekatan Praktik. Jakarta: Rineka Cipta. 
Assegaff, A. dkk. 2016. Upaya Meningkatkan Kemampuan Berfikir Analitis Melalui Model Problem Based Learning (PBL). Jurnal Pendidikan Manajemen Perkantoran. Universitas Pendidikan Indonesia, Vol. 1, No. 1: 38-48.

Dwijanto. 2007. Pengaruh Pembelajaran Berbasis Masalah Berbantuan Komputer terhadap Pencapaian Kemampuan Pemecahan Masalah dan Berpikir Kreatif Matematika Mahapeserta didik. Bandung: Sekolah Pascasarjana UPI.

Eggen, P., \& Kauchak, D. 2012. Strategi dan model pembelajaran: Mengajarkan konten dan keterampilan berpikir. Jakarta: Indonesia.

Huda, Miftahul. 2014. Model-Model Pengajaran dan Pembelajaran: Isu-Isu Metodis dan Paradigmatis. Yogyakarta: Pustaka Pelajar.

Jaya, A. dkk. 2019. Implementasi Model Problem Based Learning untuk Meningkatkan Kemampuan Komunikasi Matematis dan Percaya Diri Siswa Kelas X SMA Negeri 4. PRISMA, Prosiding Seminar Nasional Matematika 2, 410-415.

Jumaisyaroh, Tanti. dkk. 2015. Peningkatan Kemampuan Berpikir Kritis Matematis dan Kemandirian Belajar Siswa SMP Melalui Pembelajaran Berbasis Masalah. Jurnal Pasca Sarjana. Universitas Negeri Medan. Vol. 5, No. 1: 87-106.

Kemendikbud. 2013. Modul Pelatihan Implementasi Kurikulum 2013. Jakarta: Badan Pengembangan Sumber Daya Manusia Pendidikan dan Kebudayaan dan Penjaminan Mutu Pendidikan Kementrian Pendidikan dan Kebudayaan.

Mahmuzah, Rifaatul. 2015. Peningkatan Kemampuan Berpikir Kritis Matematis Siswa SMP Melalui Pendekatan Problem Posing. Jurnal Peluang. Universitas Serambi Mekkah. Vol. 4, No. 1: 64-72.

Muhson, A. 2009. Peningkatan Minat Belajar dan Pemahaman Mahapeserta didik Melalui Penerapan Problem Based Learning. Jurnal Kependidikan: Penelitian Inovasi Pembelajaran, 39(2), 171 - 182.

Murtadho, F. 2013. Berpikir Kritis dan Strategi Metakognitif: Alternatif Sarana Pengoptimalan Latihan Menulis Argumensi. $2^{\text {th }}$ Internasional
Seminar on Quality and Affordable Education (ISQAE) 2013.

Nafiah, Yunin. 2014. Penerapan Model Problem Based Learning untuk Meningkatkan Keterampilan Berpikir Kritis dan Hasil Belajar Siswa. Jurnal Pendidikan Vokasi. Universitas Negeri Yogyakarta. Vol. 4, No.1: 125-143.

Risnanosanti. 2018. Kemampuan Metakognitif Siswa dalam Pembelajaran Matematik. Jurnal Pendidikan Matematika. FKIP Universitas Muhammadiyah Bengkulu. Vol. 4: 86-98.

Saputra, Nisvu. dkk. 2018. Analisis Kemampuan Metakognitif Siswa SMA dalam Proses Pemecahan Masalah. Jurnal Pendidikan Matematika. Universitas Muhammadiyah Tangerang. Vol. 7, No. 3: 473-481.

Siswono, Tatag. Y. E. 2018. Penelitian Pendidikan Matematika. Surabaya: Rosdakarya.

Sudjana, dan Ibrahim. 2009. Penelitian dan Penilaian Pendidikan. Bandung: Sinar Baru Algensindo.

Sugiyono. 2010. Metode Penelitian Pendidikan (Pendekatan Kuantitatif, Kualitatif, dan R\&D). Bandung: Alfabeta.

Sugiyono. 2012. Statistika untuk Penelitian. Bandung: Alfabeta.

Sutini. 2019. Kemampuan Metakognitif dan Komunikasi Matematis dalam Pemecahan Masalah Matematika. Jurnal Review Pembelajaran Matematika. UIN Sunan Ampel Surabaya. 4(1): 32-47.

Suyono, dkk. 2012. Belajar \& Pembelajaran. Bandung: PT Remaja Rosdakarya.

Thayeb, T. dkk, 2017. Kemampuan Metakognisi untuk Meningkatkan Keterampilan Pemecahan Masalah Matematika Siswa Kelas VIII-B MTs Madani Alauddin Paopao Kabupaten Gowa. Jurnal Matematika dan Pembelajaran. UIN Alauddin Makasar. Vol. 5, No. 1: $1-17$.

Zakiah, Nur. 2016. Meningkatkan Kemampuan Metakognitif Siswa Melalui Pembelajaran dengan Pendekatan Open-Ended. Jurnal Teori dan Riset Matematika (TEOREMA). Universitas Galuh. Vol. 1 No. 1: 1-11. 